\title{
WHAT U.S. BUSINESSES CAN LEARN FROM POLITICAL MARKETING
}

\author{
Nicholas O'Shaughnessy, University of Loughborough, United Kingdom. \\ Morris B Holbrook, Columbia University
}

\section{INTRODUCTION}

In a field of marketing dominated by a broadened definition and recognition of its role in society (eg Kotler 1972; Kotler and Levy 196?), attention has often focussed on the question of what marketing can contribute to the strategies and tactics of political campaigns (eg McGinnis 1969; Perry 1968). Yet one might also turn this question around and ask what sophisticated, wellfinanced consumeroriented businesses can learn from generally haphazard, underfinanced political marketing? Most obviously politics sells an abstract and intangible product; it sells an image of a human being; it is value laden; it often seeks to defend an unhappy record. Hence, political marketers might have something to teach those who promote commercial products with some of these same characteristics. Further, certain communication mediums have advanced to a high degree of development in political campaigns, in particular the techniques of direct mail and telephone solicitation. Here, political consultants have accumulated an extensive fund of experience based on their own rich lore and their specialization in methods made necessary by the idiosyncratic nature of the product they sell. Finally, because of chronic limitations in funding, political campaigners grow adept at discovering cheap methods and exploiting free publicity. With comparably scarce resources, many consumer-product companies might learn from the allocation decisions of political marketers.

Some limitations to generalizing from politics to consumer marketing might arise from differences between the two types of products involved. Voting for a candidate usually seems a more serious act than the purchase of a product. Voting is intimately related to people's senses of individualism and constitutional liberty. Moreover, however indirectly, voting ultimately affects the kind of society they live in. Hence, on the ground that public obligations are involved, a political campaign can demand a greater measure of legitimacy in straying into people's homes. By contrast, the commercial solicitor might create greater resentment when telephoning and otherwise contacting people. Yet, in many situations, consumer products (especially durables) also matter greatly to people and prompt high levels of pre-purchase deliberation. In such circumstances, the political and consumption processes may converge in ways that suggest the possibility of generalization between the two.

Necessarily, this paper focuses most on the work of America's political consultants. This elite group consists of professionals to whom the American politician delegates his campaign management, including responsibilities for advertising and other marketing functions. Hence, the political consultant is really a sort of product manager. We therefore draw on the somewhat scant literature on political consultants, supplemented by interviews with ten of the twenty-five or so top political consultants who regularly handle congressional, gubernatorial, and even presidential campaigns. Only at this 
high level will political communication problems share a clear affinity with those in major businesses and thereby suggest lessons to teach businessmen. Toward this end, our interviewees included Tony Schwartz (consultant to Johnson, Humphrey, and Carter), Roger Ailes (Nixon, Reagan), Joseph Napolitan (Humphrey, Marcos, Giscard d'Estaing), David Garth (Koch, Lindsey, Anderson), and James Severin (George Bush). We thank these informants in advance for their generosity in allowing us to share their insights.

In the first part of this paper we look at "types" and inquire into the identity of those industries that may be amenable to the counsel of political marketing. From these, we proceed to a consideration of more specific "techniques", "tactics", and "technologies" that may transfer from politics to the case of marketing conventional consumer products. A useful summary of our arguments appears in Table 1.

\section{TYPES}

To what products are comparisons with political communication most applicable? Clearly, political "products" comprise personalities, policies, and programs, suggesting their relevance to those types of businesses whose products contain a similar mix of human character and intangibility. Specifically, products that embody a certain level of abstraction and "promise" (such as insurance) and products personified by one individual (such as Frank Perdue) would replicate to some extent the contours of the political situation. This comparison also applies where information is complex or contradictory and not easily retained by the audience (as in the case of a complicated new product like the IBM personal computer).

The knowledge yielded by political marketing would also be especially relevant to certain controversial industries capable of benefiting from the skills of public presentation that the politician has to offer. Cigarette companies, major industrial pollutants, and those investing in police states such as South Africa might all fall into this category. Emphatically, we do not condone the adoption of the political communications approach to justify the existence of such industries. We merely observe that such controversial cases would most likely turn to politically inspired solutions. Indeed, political consultancy first arose because Whitaker and Baxter won an initiative opposing a power company that wished to flood a valley (Perry 1968). The company subsequently hired them. Industries whose work is surrounded by controversy are by no means the only prospects for politicized marketing. Another category included those who offer some promise about the future, some kind of attractive life vision. Health clubs, with their assurance of a fitter and better physique would come under this heading as would, for example, holiday homes or anything whose satisfaction is not immediate but long term, vague, and uncertain. Such intangible and postponed gratifications are the essence of the political promise. Indeed, in this sense, American politics falls into the same category as self-improvement and investment programs.

Service industries are especially relevant here because, like the politician, they are in the business of selling not tangible products but perceptions. Services cannot be proved, compared, or demonstrated as easily as a product; rather, their success lies in the future so that their credibility has to be inferred from image building. Similarly, political marketing must communicate competence to deliver so as to penetrate the sediment of cynicism deposited by accumulated decades of lying politicians. As an opposite case, in the United States, professional services such as law, medicine, and accounting are extensively marketed in ways that could probably benefit from the advice of political consultants. Indeed, one 
T A B L E 1

MATRIX

We May Design a Matrix Structure Thus

\begin{tabular}{|c|c|c|c|c|}
\hline & & $\begin{array}{c}\text { I } \\
\text { Characteristics of } \\
\text { political products }\end{array}$ & $\begin{array}{l}\text { II } \\
\text { Resultant special } \\
\text { feature of political } \\
\text { marketing }\end{array}$ & $\begin{array}{l}\text { III } \\
\text { Examples of successful } \\
\text { application in consumer } \\
\text { marketing }\end{array}$ \\
\hline$a$ & Intangible & $\begin{array}{l}\text { Promotions, criticism } \\
\text { claims; non-payable; } \\
\text { vague benefits; } \\
\text { prosperity. }\end{array}$ & "Image" advertising & $\begin{array}{l}\text { The Marlboro Man; } \\
\text { Charley girl. (Scope } \\
\text { emotional appeal.) }\end{array}$ \\
\hline b & $\underline{\text { Human }}$ & $\begin{array}{l}\text { Human personality } \\
\text { Need for reassurance } \\
\text { Emphasis on promise }\end{array}$ & $\begin{array}{l}\text { Talking head } \\
\text { Assuasion }\end{array}$ & $\begin{array}{l}\text { Corporate spokesman; } \\
\text { Frank Purdue; } \\
\text { Cigarettes, polutants, } \\
\text { threats to democracy, } \\
\text { Health clubs, Holiday } \\
\text { Homes. }\end{array}$ \\
\hline c & Risky payoff & $\begin{array}{l}\text { Placing trust in } \\
\text { their competence }\end{array}$ & Patriotic appeals & Chevy, Bud. \\
\hline $\mathrm{d}$ & Minor mistakes & $\begin{array}{l}\text { Fallibility } \\
\text { Image problems }\end{array}$ & $\begin{array}{l}\text { "Apology" strategy } \\
\text { Rejuv nation }\end{array}$ & $\begin{array}{l}\text { Tylenol } \\
\text { New coke. }\end{array}$ \\
\hline e & Comparative & Denigrate opposition & $\begin{array}{l}\text { Negative advertising; } \\
\text { humour }\end{array}$ & $\begin{array}{l}\text { "Where's the beef"; } \\
\text { Pepsi challenge. }\end{array}$ \\
\hline $\mathrm{f}$ & $\begin{array}{l}\text { Insincere/ } \\
\text { selfish }\end{array}$ & Rhetoric; deceit & $\begin{array}{l}\text { Newspaper story } \\
\text { format }\end{array}$ & Advertising hype, \\
\hline 9 & Indivisible & $\begin{array}{l}\text { Segmentation; Targeted } \\
\text { - personlised media }\end{array}$ & $\begin{array}{l}\text { Consistency. } \\
\text { Narrowcasting; } \\
\text { direct mail; } \\
\text { canvassers. }\end{array}$ & $\begin{array}{l}\text { Selective Segmentation; } \\
\text { Pink Flamingoes (spoil } \\
\text { the neighborhood). }\end{array}$ \\
\hline $\mathrm{h}$ & $\frac{\text { Subjective }}{\underline{\text { benefits }}}$ & Manipulation & Rhetoric & Deceptive wording. \\
\hline
\end{tabular}


sometimes finds points of direct interaction. For example, a course for judges recently available in California was entitled "Campaigning with dignity, maintaining the judicial image". Hence, the tactics of political communication are applicable to particular business situations as well as to particular business forms.

One also finds an application of political marketing techniques to major corporate disasters. Fortunately, a Bhopal, a Three Mile Island, or a Tylenol occurs relatively rarely so that the risks for the average corporation and its customers remain fairly low. But the small number of spectacular calamities that occasionally do occur almost always open the way for politically inspired marketing solutions.

Less spectacularly but more frequently, the corporation finds itself facing some sort of mundane marketing failure. For example, a product might have developed a negative image as outdated or inefficient. The situation here closely resembles that of a politician in trouble with his electorate. Political consultants have devised a host of tactics for dealing with such problems. They may simply choose to deflect attention by attacking opponents vigorously. Or they may stress plans for the future and proclaim a radical change, emphasizing what is new about the candidate, as with the "new" Nixon eulogized in 1968 and avowedly reformed from the devious figure of public imagination (McGinnis 1969). Thus, when applied to consumer marketing, consultants' strategy might seek to formulate and to proclaim a break with the past so as to establish a new identity for the product and for the firm. Even if the old identity is retained, it will be played down while emphasizing the obstacles (eg ruthless foreign competition) that the company has successfully overcome so that past failures disappear into a larger context of heroic struggles (preferably, documented by the appropriate historical documents and statistical evidence). This is not to say that such symbolic reconstructions of product and company are not currently done. We merely suggest that political marketers have acquired far more experience at it and do it better as a result. Consider, for example, how a reinvigorated Republican Party emerged only a few years after its Watergate nemesis - in large measure through the assistance of effective political marketing.

It follows. that political marketers and consultants have most to offer business in the realm of public relations where the overall image of a company affects the sale of its products so that corporations seek control over all aspects of their public presentation and fear negative publicity. Consequently, for many years now, corporate image-building has been an enduring fashion as companies seek a distinct identity, an emotive label, whether "high quality" or "efficient" or "trustworthy" or "big hearted" or "stylish". Such positive images nurture the welfare of individual products in that the products assume the overall corporate identity. In this connection, political consultants have spent years in the professional task of image building for candidates and parties. This area has become their central competence, one clearly related to the problem of building up a corporate personality and one into which conventional advertising may have more limited insight.

As a special case of image-building, the marketing of non-profit organizations may especially benefit from the political experience. The areas such organizations work in are more in the public domain than orthodox business and, therefore, more permeated with political-type problems such as those that confront a trade union, a national institution like the post office, or a charity. Such organizations face heavier scrutiny from the press even while their performance is difficult to measure, in part because it is intangible and 
abstract. Often, they encounter ideological controversy when they assume publicly controversial stands. Meanwhile, in the face of limited resources, they often lobby for state assistance. Hence, the fund raising experience of consultants (eg in the use of computer generated direct mail) might greatly benefit the non-profit sector.

\section{TECHNIQUES}

We now turn to the role of professional campaign managers - the political consultants - and seek to define the nature of the contribution they could make to commercial operations.

The political achievement of consultants is clear. Consultants have successfully targeted and exploited welldefined groups in society. Above all they have helped move what seemed a highly consensual social orthodoxy further in the direction of their own prejudices. Thus, everywhere, their operations illustrate the mutability of public opinion. Similarly, business can change popular convention on issues that affect it, by targeting propaganda on opinion leaders, by using tailored and targeted media, and by building up a cadre of supporters for a cause.

\section{Their Skills}

Why do the consultants who merchandise America's candidates have such special skills of public presentation? First, they typically draw upon a vast fund of experience, handling anything up to twelve campaigns in one election. Congressional elections are held every two years - not to mention elections and the jamboree of the Presidential campaign. In each of these, the power of media scrutiny, the publicly adversarial relationship, will outweigh that ever faced by most Chief Executive Officers of corporations. Second, candidates are vulnerable over a wide range of areas - including those of concern to people prying into private lives, those attracting the scrutiny of
America's various pressure groups, and those raised by the active supporters (especially the political action committees) who actually pay the campaign bills. Third, many of America's politicians do not rise by some established political career track as in Britain. Rather, they are often outsiders, such as rich men seeking a public role. Consequently, they often amateurs, in need of consultants to supply a professional veneer. Fourth, political consultants are skilled at dealing with hostile members of the press. In many campaigns, the press conference exposes the candidate to the glare of national exposure on a daily basis. Hence, compared with commercial advertisers, political consultants deal with a much more attentive audience. Television political advertising has a seventy-nine percent viewer recall, versus twenty-two perce$\mathrm{nt}$ for normal commercial advertising.

\section{The Chairman Star}

With voters who often cannot relate to issues, an uncommitted vote coupled with a sharp decline in party affiliation, and problems so complex that we avoid trying to comprehend them ourselves by seeking an individual who can, image building has become central to the political campaigns. Similarly, it is a truism that image is also increasingly important in business. Heads of American corporations star increasingly in their own commercials (Borman, Iacocca, Purdue), and for many years now, there has been a strong tendency to take some real personality or mythical figure to embody the product and firm - as John Houseman did for Smith Barney, the investment bank ("They make money to old-fashioned way ...."). Political consultants are specialists at building up images for candidates. One might wonder whether advertising agencies, which necessarily focus on a broader set of promotional ideas, have attained the same level of expertise in the projection of the individual.

When Presidents of corporations 
appear in advertising, the device still works because of its boldness and novelty. However, its potential may not be fully exploited. Usually, the President is put awkwardly into a context like that given to any other advertising presenter. From the consequent tentative performance one might conclude that to use corporate presidents as one would trained actors is a recipe for having them perform like lifeless mannequins. Rather, political consultants could teach us much, aware that the art lies in finding the right setting where they perform effectively. With their intuitive understanding, they are skilled at suggesting possibilities. For example, most corporate presidents will be masters of some sort of setting or situation where they can behave spontaneously and with authority. The task is to identify which one.

Political consultants (eg Severin 1987) are highly critical of orthodox "image" advertising. On using the chairman himself to sell the product, James Severin (George Bush's consultant) points out that this ploy seldom relates to the substance of the campaign theme. Severin believes that somehow the chairman must come across as "every man" - a person like Iaccoca, whom viewers can identify with. Iaccoca (the chairman of Chrysler) appeared in the guise of every man, with the personal qualities of being self-made, rising from the bottom, and therefore remembering the values shared with the larger community, values guaranteeing a concern for high-quality products. In contrast, Frank Borman's performance (as president of Eastern Airlines) meant little according to Severin because he simply came across as a "tough @\#\%\&\#@*\&". In short, using the corporate chairman must signal reliability and not just a phoney expedience. Consultant Joseph Napolitan (Hubert Humphrey, Giscard d'Estaing, etc) echoes Severin's praise of Iacocca (Napolitan 1987). Roger Ailes (1987) is also scathing about attempts of businessmen to star in their own commercials: for every Iaccoca, there is someone who runs a used car lot, who either wants to be on camera himself or doesn't want to pay an actor so he just does it himself. That sets the whole image back 20 years.

Often, political image building starts from a point of zero recognition and works from there toward a recognizable candidacy. The same could be done for the corporate chairman, especially since political consultants have become adept at selling people with little dramatic flair and even with unappealing features. They turn plain men into credible advocates. Many corporate spokes people could benefit from similar transformations.

In summary, the corporate representative whose company falls under public scrutiny might turn to consultants to provide the best grooming and communication strategy. Messages aimed at specific groups associated with the company - employees, say, or shareholders - could be fine-tuned by them, as could general company image building targeted to the broad public. Because such situations are essentially political in character involving a person, an image, an argument, an idea, the best advisers may be those most experienced in political communication.

\section{Executive Training}

When political consultants do emphasize their ability to train executives as general persuaders and communicators (profiting from the increasing importance business places on communication skills by retraining nervous communicators to cope with the dinner audiences, press, shareholders, and television), there is no scientific way this can be done. Rather, it is an interpretative exercise depending on the expertise and intuitive insight of the trainer. Roger Ailes (1987) tells of the types of people interested in such performance critiques - high executives facing interviews for new jobs, rising 
entrepreneurs having to raise Wall Street money, and so on. He adds, "In fact, my theory is that nobody will ever by selected to run a major company unless he or she meets some selected communications criteria". Pointing out that entrepreneurs sell ideas, Ailes speculates that many fail because they cannot communicate.

Consequently, political consultants currently do a great deal of mainstream business work. Roger Ailes, formerly a top consultant to Reagan and Richard Nixon, can number American Express, Celanese Corp, AT\&T, Union Carbide, Polaroid, and Johnson and Johnson among his clients. Republican James Severin can include Pan Am alongside the Social Democratic Party of Brazil. David Garth has worked for Dime Savings Bank and Avis. Ailes also offers other services to business: corporate commercials, films for employees, etc. His repertoire extends to personal selling, the development of new product or service ideas, and the enhancement of negotiating abilities. Political consultants such as Joseph Correll (President of the American Association of Political Consultants), are also moving into mainstream public relations. Here, they are well placed since their political connections are excellent and therefore potentially useful to businesses seeking favorable legislation. Thus, when Texaco wished to obtain a loan guarantee for the production of synthetic fuels, it hired consultants (Black, Manafort, Stone and Kelley). In another instance, consultant James Severin had Mr. Reagan present shirts with his client's logo at a televised ceremony. Consultants can thus offer a level of critical political access which other organizations could not supply by providing a unique rapport with parties and individual legislators. In this connection, Severin's firm offers all the customary services of an advertising agency plus contact with public agencies and officials.

\section{Other Services}

Severin claims additional advantages to business in using political consultants. For one thing, they are well-disciplined. They have at most one year to gain a $51 \%$ market share "or are bums". By contrast, a soft drink firm might be satisfied with a $6 \%$ share. Political consultants are geared to measurable results within a strict timetable. Further, in advocating advertising, political consultants specialize in selling an intangible vague promise of the future. Hence they have become adept at the simple and symbolic expression of the abstract and complex.

Also valuable is the strategic sense and flexibility that consultants exhibit in conducting a campaign. They deal with a much more volatile situation than that typical of most consumer products. Here, they specialize in the creation of artificial issues, ones which are strategically valuable to a politician and are made prominent by the interactive force of constant advertising (Severin 1987). Thus consultant Roger Ailes (1987) feels political consultants can play a significant role in business strategic planning. In particular, he stresses the speed of the service that political consultants can offer. All their experience and training focusses on the quick turnaround situation. They can give the same service to business. For example, a normal commercial can easily take six months to make and cost several $\$ 100,000$; the political commercial would probably cost a maximum of $\$ 20,000$ and could be made in two or three days. Ailes perceives political consultants as essentially damage control experts, good at dealing with the immediate problem. $\mathrm{He}$ describes them as a high intensity combat group and believes that, in cases such as Union Carbide and Tylenol, they could make a contribution.

\section{TACTICS}

So far, we have asserted that certain business situations raise problems analogous to those that political communic- 
ators purport to deal with and that their experience has therefore created a richness of applied wisdom which business could profitably absorb. But it is unsatisfactory to base this argument solely on the alleged insightfulness of the political actors. Rather, we must seek conceptual innovation and novel methods of persuasion that political consultants can offer. True, consultants derive many of their methods from commercial practice. However, in this section, we focus on various advertising approaches that have been pioneered by political consultants.

\section{Negative Advertising}

The first, negative advertising, has profoundly influenced the course of modern American politics and reached its climax in the 1986 Congressional elections. The "new right" gave it modern format (Crawford 1980), but its origins go right back to the beginnings of political advertising when Whitaker and Baxter opposed Upton Sinclair in the prewar California gubernatorial elections. By comparison, corporate advertising is better mannered - reflecting perhaps the bureaucratic passiveness of many corporations.

Would corporate advertising benefit from a greater injection of aggression? For a time it could certainly work because of its novelty value. Current$1 \mathrm{y}$, there is some comparative advertising, but this remains next to what a political consultant might prescribe. The circumstances in which negative advertising could work for commercial products are restricted. There would have to be only one or two clearly identified rival boards. Moreover, there are restrictive standards. Business cannot lie, as a politician has some license to do (Sabato 1981). Moreover, attack is a challenger's strategy; it is effective when a leader has been around a long time and people are becoming bored. Also, real quality is needed to sustain a position once it has been gained by such means. Thus, the med- iocre Republican Senators elected through the agency of negative advertising in 1980 could not repeat their victory in 1986. Further, psychological factors may inhibit the commercial use of negative advertising. For example, we may anticipate some consumer resistance. In its political context, negative advertising may backfire as a result of the underdog syndrome (O'Shaughnessy 1987). We might infer that the same applies to an underdog product with a clear identity and personality.

In the many examples of negative political advertising, much depends on the tactical execution and on the insight of the copywriter. Sometimes, as when a rightist pressure group produced an anti-Ted Kennedy comic ("Every family has one") about a fat black sheet, the genre reaches its nadir (Sabato 1981). But, when well used, the device can be lethally effective. For example, Joe White produced one commercial in which an announcement that the incumbent Senator's achievements for the State would be listed was followed by 30 seconds silence (White 1987). Negative advertising is used in politics because of its power. We might denounce the public cynicism such campaigning creates and might argue that the social effects of its commercial use would be deleterious. But the methods work. And such campaigning might be an incentive to higher product standards.

\section{Admission Strategy}

Next, political consultants have sponsored several newer advertising techniques. One popular technique invented by David Garth was the "admission" strategy. Its pedigree is impressive, working for Lindsay and Carey, among others. Here, the politician confesses past error, and the public warms to such rare, refreshing honesty. Presumably, they would do the same for a company. But an important qualification should be made. In politics, the "confession" is seldom absolute: it only 
concedes errors that seem eminently reasonable. This demonstrates the wealth of tactical rather than theoretical knowledge that politics can transmit to business. Like all such tactics, it can be reduced to parody, as in the film "The Candidate". When Robert Redford replies "I don't know" to a reporter's question, the consultants seize on this gaffe and market it as a unique expression of political integrity. Such consultants are certainly adept at turning potential liabilities into assets. Democrat consultant Joseph White gives the example of the Governor of Alaska who had a lifelong speech impediment which jeopardized his initial candidacy. White turned this into a selling point, explaining how, when born with this sort of problem, one has to fight twice as hard in life. Business might make use of similar strategies.

\section{Talking Head}

Another format that has worked effectively in American politics is the "talking head" (Perry 1984). Since the individual confronts his public shorn of trappings, this conveys an impression of austerity and honesty. Using this technique, some politicians have gained dramatic results. Similarly it could be used in changing and upgrading products, most especially as an image corrective when a product aspires to a more serious image. An alternative employment would be in corporate image advertising, and this would apply particularly to companies under attack from pressure groups, environmentalists, etc. By analogy, throughout his early campaigns, Reagan was a moderate performer. Only late did they discover the effect on audiences of his facing straight into the camera and using his expressive voice. In this posture he could hold the attention of $70 \%$ of the audience for 36 minutes (Percy 1984).

\section{Language}

The political use of language may be worthy of emulation. Too often, the cryptic jargon of business thwarts the art of persuasive verbal communication. Further, advertising should recognize that language can communicate an aura as well as a meaning. In politics language is used for the same ends as in commercial advertising - namely, for the task of persuasion. But, partly because many of them are elected not by a homogeneous group but by a strategic coalition, politicians develop a heightened sensitivity to language carefully selecting their words to reconcile sometimes contradictory positions and to avoid alienating different constituencies. Reagan is (or was before Irangate) noteworthy as much for his ability to choose moving language as for delivering it movingly.

Having written for top-level figures including Presidents, political consultants know how to make language memorable without also making it vulnerable. Above all, they recognize the uses of language to change perception. For example, the Republicans had a special team entrusted with the task of developing a "new rhetoric" that would encapsulate the rightist perspective. Reagan himself was told to the use word "peace" five times in every speech during the 1980 campaign, and a new terminology was evolved for him to suggest a "peace posture". As Governor of California, Reagan had an alternative to the Great Society. It was called the Creative Society. In the words of one critic, "Whatever Reagan wanted to do, it was creative. Shut down Berkeley? It was creative" (Perry 1984).

Similarly, careful choice of language can subtly endow a product with a new set of associations (again, as usual, for good or for ill).

\section{TECHNOLOGIES}

\section{Direct Mail}

Direct mail has been a central weapon in the arsenal of political consultants (O'Shaughnessy and Peele 1985). 
Political consultants have been pioneers of direct mail. It has had spectacular success in changing the political map of the USA and has been a major tool in the march from social liberalism. It was the main vehicle in the build-up of Republican party finances in the postWatergate period. Political groups therefore have experience of the persuasive powers of direct mail. For example, the rightist consultant Richard Viguerie has the names and addresses of 30 million conservative Americans on tape in a guarded vault.

Direct mail is effective in politics because it associates the recipient with things that are significant in the culture - patriotism, family life, etc. Moreover the idea communicated is of joining something - not merely purchasing an artefact, but becoming part of a social movement. At least some kinds of product would be amenable to similar types of appeal.

Specifically, political mail is the demagogue's own medium, and through its agency "new right" entrepreneurs have raised fortunes. Direct mail copywriters skillfully foment emotion. They make no effort to build up a reasoned case. Arguments always present an exaggerated picture which even true believers know to be overdrawn (Crawford 1980). Yet the fact is that direct mail successfully sells an abstraction. In contrast, consumer direct mail seldom exhibits the same sophistication as other commercial advertising media. Rather, it almost appears to have the character of an afterthought. Nor do commercial direct mail campaigners exploit emotion beyond material desire. There is little passion in what they do. Clearly, for some products, passion is irrelevant. For example, few would feel genuinely infatuated with a food mixer. But other products do potentially involve deep emotion - the connection between insurance and fear, for example. Here, business might learn something from politicians in its potential use of histrionics. Also, political mailings seem to achieve a precision of segmentation through their use of large amounts of census data, ethnicity tapes, etc. We suggest that the targeting of commercial direct mail is often vaguer, more general, and therefore less effective. This point remains supposition until validated by empirical research.

Everything in political marketing illuminates a trend towards an anodyne armchair activism - a phenomenon sometimes referred to as "the couch potato". The modern population is especially bound by its comfortable home and its technology and is prepared to be active only within these confines. Hence, appeals made to this particular contextual setting are having increasing success. This explains the potency of direct mail and other types of direct marketing operations in US politics. The consumer marketer may need to make it possible to perform decision-making and purchasing activities within the home. Indeed, certain trends such as telex and video shopping appear to be moving in this direction.

\section{Polling}

James Severin believes that polling the political variant of market research, has been developed to a sophisticated degree. The image of polling has been tarnished by the mediocre product purchased by the networks and newspapers based on poor sampling techniques and badly worded questions. But Severin claims the methods used by consultants can get to the heart of the matter. Addressing the key question "why do you care?" the consultant must find something that will make a difference to electorates and must uncover the key values they hold. Hence, consultants design questions that go far towards eliciting this and seek ways of overcoming inner resistance within the target. Political pollsters therefore believe they have become adept at asking questions that probe. They recognize how misleading conventionally attained results can be. Thus for in- 
stance the names of parties may be kept out and particular values substituted instead (eg "Free enterprise party") (Sabato 1981). The idea is to penetrate the barrier of reserve, to get past the wish to sound socially appropriate. For example, racial attitudes can only be discovered in this way since few people will admit the existence of prejudice. Such a technique would have been particularly useful in assessing support for Reagan, many of whose votes came from people who were reluctant to say so. David Garth, in particular, is skeptical about conventional market research - whose techniques, he says, are "not so much in depth as deep in pocket". According to Garth, political surveys have a higher yield of rich information. For example, he used political pollsters in his work on an advertising campaign for Avis.

Since the complexity of the political "purchase" situation - low on information content and high on vagueness demands delicate measurement, these claims by the consultants may have substance. But again, their assertions require careful empirical evaluation. Certainly, political polling seems to have some affinity with the Motivation Research pioneered by Ernest Dichter (1960, 1985) and may suggest the value of some return to those methods.

Meanwhile, the dangers inherent in polling dramatize the problems of all market research. They show that seemingly confident answers can mask ignorance and disinterest. For example, in one poll, a third of the respondents had firm opinions about a wholly mythological 1975 Public Affairs Act. Another poll claimed that $77 \%$ of interviewees were unable to name the two countries engaged in the SALT II negotiations. Further, different wordings of similar questions can elicit different responses. Thus, in the 1983 British general election, the Labor Party's advantage on "unemployment" (13\%) was much higher than on "jobs" (7\%). Hence, market research must beware of the assumed extent of public knowledge. People will claim a knowledge they do not possess and will offer highly colored interpretations of meaning. For example, one consumer survey in which the second author participated tangentially produced a significant level of claimed usage for a non-existent brand of coffee.

Political polling also illuminates the risks of over dependence on research data. Excessive concern with polling limits the politician's scope of action, just as a businessperson can be overly obsessed with market research. Thus, in politics, extensive polling has surely induced an obsession with short-term expediency in which the polls give no credit for forward planning (Butler and Kavanagh 1984). Similarly, businesspersons can be led by market research into as concentration on short-term horizons and dividends. Hence, they may neglect to plan for the long-term, seeking only tangible returns in immediate profits, and momentary psychic income. Too often, communication tactics seek to combat the pressures of the moment. As such, they assume the quality of panaceas. They can easily direct attention from strategy. This is true of modern politicians enmeshed in their perpetual public relations battle, relying on secondary actors and performing before the arc-lights of publicity at the price of an increasing forfeiture of their real power. Similarly, businesses can be over-concerned with communicating to key current constituencies and neglect the future. When communication is made a thrust , it can all too easily become the thrust.

\section{CONCLUSION}

Politicians and businesspeople often try to do similar things - to convince or to persuade without proof based only on the credibility of the individual. This suggests that American business might find a use for political consultants and come increasingly to value their services. In the highly politicized 
context in which American business now operates, we might expect that American firms and political consultants would move toward some sort of symbiotic relationship.

But this prediction and its potential effects require some sort of empirical testing. Consultants are bound to exaggerate their importance. They are, after all, businessmen, and they inhabit a domain not noted for its modesty. We have advanced a case for the logic of their claims. But we await further evidence that the claims are true.

Towards this end, respondents from business might be surveyed and various questions asked:

* Have they ever used or contemplated using political consultants?

* In what areas have they used consultants; what was the quality of the consultants' contribution?

* If they have never used them, are they aware of the function of political consultants; what do they think consultants can contribute to business?

* Do they agree with claims made by the consultants?

* Might they use political consultants in the future?

Such a questionnaire would only cover certain business practices and would be restricted to larger firms where the use of commercial consultants is already part of the corporate culture. It could usefully be extended to non-business areas such as municipal councils and state governments, who may have more need for the services of political consultants. The field is open for future empirical research. We eagerly await this next development.

\section{REFERENCES}

.1 Perry, James, M., "the New Politics", Weidenfeld and Nicolson, 1968.

2 McGinnis, Joe, "The Selling of the President 1968", Trident Press, New
York, 1969.

3 Saloma, John S., Ominous Politics, Hill and Wong, New York 1984.

4 Interview with James Severin, Severin Aviles Inc., New York, January 1987.

5 Interview with Joseph Napolitan, Joseph Napolitan Inc., New York, January 1987.

6 Publicity documents issued by Ailes Communications Inc. and Severin Aviles Inc.

7 Interview with Roger Ailes, Ailes Communications Inc., New York, January 1987.

8 Interview with James Severin.

9 Interview with Roger Ailes.

10 For a review of "New Right" activities see Crawford, Alan, "Thunder on the Right", Pantheon Books, New York, 1980.

11 Nimmo, Dan, "The Political Persuaders", Prentice Hall Inc., 1970.

12 For accounts of deceitful methods see Larry Sabato, "The Rise of Political Consultants: New Ways of Winning Elections", New York, Basic Books Inc., 1981.

13 O'Shaughnessy, Nicholas J., "America's Political Market", European Journal of Marketing, Vol 21, No 4, 1987.

14 Sabato op cit.

15 Interview with Joseph White, Joseph White Inc., New York, January 1987.

16 Perry, Roland, "The Programming of the President", Aurum Press, 1984.

17 Perry, op cit.

18 Perry, op cit.

19 For a review of direct mailing techniques in American politics see O'Shaughnessy and Peele, "Money, Mail and Markets", Electoral Studies, Vol 4, No 2, August 1985.

20 For examples of right-wing political direct mail see Crawford, op cit.

21 For information on political polling see Sabato op cit., Perry op cit. See also Perry, James M., "The New Politics".

22 For review of the potential strengths of polling see Sabato op cit.

Continued on page 14 
Continued from Page 70

12. Id at 1339.

13. Donovan v. Federal Clearing Die Casting Co., 655 F. 2d 793 (7th Cir. (1981).

14. Donovan v. Wollaston Alloys, Inc., 695 F. 2d 1 (1st Cir. 1982)

15. Donvan v. Enterprise Foundry, Inc., 751 F. 2 d 30 at 38 (1st Cir. 1984)

16. 436 U.S. 307 (1978).

17. Donovan v. Hackney, Inc., 769 F. 2d 650 (10th Cir. 1985).

18. Donovan v. Enterprise Foundry, Inc., 751 F. 2 d 30 (1st Cir. 1984)

19. Burkart Randall Div. of Textron, Inc. v. Marshall, 625 F. 2d 1313 at 1325 (7th Cir. 1980)

20. Matter of Establishment Inspection, Etc., 589 F. 2d 1335 at 1343 (7th Cir. 1980).

21. Donovan v. Wollaston Alloys, Inc., 695 F. 2d 1 (1st Cir. 1982)

22. Donovan v. Burlington Northern, 694 F. 2d 1213 (9th Cir. 1982).

23. Marshall v. Milwaukee Boiler Mfg. Co., Inc., 626 F. 2 d 1339 (7th Cir. 1980)

24. Burkart Randall Div. of Textron, Inc. v. Marshall, 625 F. 2d 1313 at 1332 (7th Cir. 1980

25. Donovan v. Hackney, Inc., 769 F.2d 650 at 653 (10th Cir. 1985)

26. Burkart Randall Div. of Textron, Inc. v. Marshall, 625 F. 2d le13 at 1319 (7th Cir. 1980)

27. Brooks v. Brooks Woolen Co., Inc., 782 F. 2d 1066 at 1973 (1st Cir. 1986). 28. New York v. Burger, 107 S. Ct. 2636 (1987).

29. Id at 2642.

30. ibid at 2652 .

31. Brooks v. Brooks Woolen Co., Inc., 782 F.2d 1066 at 1974 (1st Cir. 1986).

\section{Continued from Page 49}

18. Leland, H.E. and D.H. Pyle, "Informational Asymmetries, Financial Structure, and Financial Intermediation," Journal of Finance, 32, (May, 1977), pp 371-387.

20. Mancuso, J.R., "How to name and not name a business," Harvard Business Review (November-December, 1978), pp. 25-27.

21. Myers, S.C., "Determinants of Corporate Borrowing," Journal of Financial Economics 4, (November, 1977), pp. 147-176.

22. Ross, S.A., "The Determination of Financial Structure: The Incentive Signalling Approach," Bell Journal of Economics, 10 (Spring, 1979), pp. 23-40.

23. Simon, H.A., "Theories of Decision Making in Economics and Behavioral Science," American Economic Review, 49, (June, 1959), pp. 253-283.

24. Smith, A. The Wealth of Nations. 1776. Cannan Edition. New York: Modern Library, 1937.

25. Spence, A.M., "Job Market Signaling," Quarterly Journal of Economics, 87, (August, 1973), pp. 353-379.

26. Williamson, O.E., The Economics of Discretionary Behavior: Managerial Objectives in a Theory of the Firm. Englewood Cliffs: Prentice-Hall, 1964.

27. Working, H., "A Random Difference Series for Use in the Analysis of Time Series," Journal of the Am. Statistical Assoc., 29, (March, 1934), pp. 11-24. 